\title{
The Role of Land Reform Beneficiaries and the Reasons for Them Developing and Supporting a Satellite School in Masvingo, Zimbabwe: A Social Capital Marriage of Nhimbe and Allied Reasons
}

\author{
Kudzayi Savious Tarisayi \\ https://orcid.org/0000-0003-0086-2420 \\ University of KwaZulu-Natal, South \\ Africa \\ TarisayiK@ukzn.ac.za
}

\author{
Sadhana Manik \\ https://orcid.org/0000-0001-7687-0844 \\ University of KwaZulu-Natal, South \\ Africa \\ Manik@ukzn.ac.za
}

\section{Abstract}

The land reform process in Zimbabwe gave birth to a new type of school known as a satellite school, which emerged due to community requests (in areas populated by land reform beneficiaries) and an inability by government to adequately fund new schools that communities required. Various studies on the emergence of satellite schools have mainly focused on the challenges faced by satellite schools. This article explores nhimbe ("work party") and allied reasons specifically amongst the land reform beneficiaries who provide a supporting role to a satellite school in their community. This paper offers a different perspective on satellite schools from the vantage point of the land reform beneficiaries who are choosing to fill an educational gap and simultaneously nurture the development of an educational asset which they built - the satellite school. Theoretically, social capital frameworks by James Coleman (1988) and Robert Putnam (2000) are utilised to understand the relationships forged and maintained between groups of people for a greater good, in this case the land reform beneficiaries' construction and ongoing support of one selected satellite school. Although the study's research design adopted a multiple case study approach, we use the case of a group of land reform beneficiaries in one district for this paper. The data were elicited through semi-structured interviews and focus group discussions held at one satellite school in the Masvingo district of Zimbabwe. The purposively selected participants comprised six land reform beneficiaries, two village heads and one satellite school head, making a total sample of nine participants. The study revealed that the land reform

\section{UNISA $\cong$}


beneficiaries played a central role in the development and support of the satellite school in their community because of a marriage of interrelated reasons. These included the close proximity of their homesteads to each other which generated nhimbe, which further developed their relationships, their social networks, a sense of homage coupled with an indebtedness to the Mugabe government, shared community goals and social norms and the existing resource base (that they could access in their community). The study revealed that all these reasons for the land reform beneficiaries developing and supporting the satellite school feed off each other - they are not independent of each other. We conclude that the land reform beneficiaries have a sense of ownership of the satellite school in their community in Masvingo and they resultantly strive to use the available resources they are able to muster to develop the school so that it can be a valued asset to their community.

Keywords: satellite schools; land reform beneficiaries; Nhimbe; Zimbabwe

\section{Introduction}

Satellite schools emerged during the land reform process in Zimbabwe as a response to the absence of schools in resettlement areas (Mutema 2014; Tarisayi and Manhibi 2017). The realisation that the children and dependents of land reform beneficiaries ${ }^{1}$ were walking long distances and sometimes across dangerous territory (crossing flooded rivers) to faraway schools led to the birth of satellite schools in communities (Tarisayi 2017). The land reform process led to a demand for education in the former commercial farms (Parliament of Zimbabwe 2012) which were now subdivided and allocated to citizens. Thus, the land reform process in Zimbabwe created a demand for schools in the newly formed land reform communities. The education budget was unable to cater for this greater number of schools that communities were requesting to be built. Hlupo and Tsikira $(2012,604)$ also report that "Zimbabwe's education sector suffered greatly during the years of the economic crisis with declining budgets." Thus, although schools were required, the government was unable to meet the local need and communities then decided to rally together and partner with the government. The government agreed to provide teachers, but communities had to build their own schools using their own resources (Tarisayi and Manik 2017). Hlupo and Tsikira $(2012,605)$ opine that land reform "worsened the already underfunded and under-resourced education sector at all levels." The need for schools was addressed by the construction of satellite schools by communities (Mutema 2012; 2014; Parliament of Zimbabwe 2012) upon receiving approval by the government. Hence, although there was a reduced national education budget, there was an increase in the number of schools built due to the construction of satellite schools. Shizha and Kariwo (2011) argue that land reform in Zimbabwe was responsible for causing an economic crisis that negatively affected the education sector. The resulting economic crisis meant that the government no longer

Black farmers who received land which had been grabbed from white commercial farmers during the land reform process in Zimbabwe. 
channelled adequate resources towards the education sector. Resultantly, the learning environment in the newly constructed satellite schools was deplorable as substandard infrastructure such as tobacco barns and farmhouses were being used as schools (Parliament of Zimbabwe 2012; Zvavahera 2015).

Studies on the emergence of satellite schools in Zimbabwe (Hlupo and Tsikira 2012; Kabayanjiri 2012; Mutema 2012; Shizha and Kariwo 2011; Tarisayi 2015; Tarisayi and Manhibi 2017) have surprisingly overlooked the reasons for the central role played by land reform beneficiaries in the development and support of satellite schools in their communities. Tarisayi and Manik (2017) in a previous paper established that land reform beneficiaries played a central role in the development and support of satellite schools through resource mobilisation and information sharing. Their paper revealed that land reform beneficiaries were involved in providing accommodation to teachers, their own physical labour, building materials and financial support (Tarisayi and Manik 2017). Land reform beneficiaries also participated in stakeholder meetings about the school, lobbying the government for the provision of a school, linking their school with prospective donors and enrolling their children in the satellite school. Thus given all these mentioned benefits that have accrued as a result of the land reform beneficiaries' participation in the development and support of a satellite school, it is imperative to understand the reasons why land reform beneficiaries have chosen to commit to the satellite school in their community. Previous scholarship established that social capital is a critical resource in the development of satellite schools. This paper examines the social capital marriage of the traditional agricultural practice of nhimbe with other reasons as a critical resource with regards to the role of land reform beneficiaries in the development and support of a satellite school in Tiro. We argue that the land reform beneficiaries could be a significant contributor, once recognised, in the development and ongoing support of satellite schools and this could consequently improve education infrastructure in the resettlement areas of Zimbabwe.

This follow-up paper commenced with an introduction that provided a background to satellite schools in Zimbabwe and it then proceeded to discuss the central role played by land reform beneficiaries in the development and support of a satellite school in the community. The theoretical frameworks guiding the paper are then presented. This is followed by a discussion of the methodology utilised to generate data. Thereafter, a discussion ensues on the research findings concerning the reasons for the land reform beneficiaries of Tiro contributing to the development and support of the satellite school in their community in Zimbabwe. We contend that land reform beneficiaries in Tiro community, Masvingo, commit to the satellite school due to a multiplicity of interrelated reasons and these reasons become critical in the development of the satellite school. Other salient conclusions on the role of land reform beneficiaries and the satellite school complete this paper. 


\section{Salient Theoretical Frameworks}

This paper, on the reasons that influence the land reform beneficiaries of Tiro to play a central role in the development and support of the satellite school in their community, is guided by the social capital theoretical strands espoused by James Coleman (1988) and Robert D. Putnam (2000). Coleman (1988) argues that social relations are a resource. Therefore, in this paper the land reform beneficiaries' social relations are viewed as resources that are central to the development and support of the satellite school in their community. Coleman (1988) further proffers a communitarian approach to social capital. The communitarian approach argues that social capital benefits are not confined to the individual but accrue to the whole community and in this paper, we explore the reasons for one community of land reform beneficiaries' continued support of a satellite school in their community.

It should be noted that Putnam is a political scientist whose work centres on ideas of democracy. He avers that social capital is more than an individual resource: it is an attribute evident in modern societies where there are large aggregations of people. Similar to Coleman, Putnam believes that social capital is an attribute which allows for interactions between people. Putnam views social capital as "features of social organisation such as networks, norms and social trust that facilitate coordination and cooperation of mutual benefit" (Putnam 1995, 67). He further explains "connections among individuals - social networks and the norms of reciprocity and trustworthiness ... arise from them" (Putnam 2000, 19). However, Putnam has been criticised for his simplistic conceptualisation of, for example, the concept of "trust." This has been argued to be far more complex than his oversimplified description avers. We later draw attention in our findings to some of the above criticisms of Putnam's work.

In this paper, the connections between the land reform beneficiaries and their norms of reciprocity are regarded as social capital. Putnam's social capital theory (2000) is valuable in unpacking the reasons for the land reform beneficiaries' support of the satellite school as it explains what makes societies both efficient and cohesive. This perspective on social capital by Putnam (2000) becomes relevant as it can be used to explain the reasons that influence the land reform beneficiaries to play a central role in the development and support of the satellite school in their community.

\section{Methodology}

The study from which this paper derives its data was on the social capital influences of land reform beneficiaries and communal farmers on the development of satellite schools. The study posed two critical questions that are relevant to this paper: How does the social capital of the land reform beneficiaries influence satellite schools? What influences land reform beneficiaries to play a central role in the development and support of satellite schools in their communities? The present paper seeks to address the following research question: What are the reasons that influence land reform 
beneficiaries to play a central role in the development and support of the satellite school in Tiro community? As part of the main study's research design, a qualitative multiple case study approach was used which involved two communities: the land reform beneficiaries of Tiro and the communal farmers of Sambo in the Masvingo district of Zimbabwe. However, in this paper we only provide the empirical findings from one case study, namely that of the community of Tiro.

\section{Case Study: Tiro Community}

The community of Tiro is composed of land reform beneficiaries who were allocated land by the government of Zimbabwe in 2003 as part of the land reform process. Prior to the construction of the satellite school, there were no schools within the community of Tiro. The nearest school to the community of Tiro was located about 15 kilometres away from the community. Tarisayi and Manik $(2017,3)$ explain that "satellite schools are unregistered schools, which are attached to established schools (also known as mother schools) for administrative purposes." Therefore, Tiro satellite school was attached to the mother school which was located 15 kilometres away for administrative purposes. The children of land reform beneficiaries had to walk a daily total distance of 30 kilometres to get to and from school prior to the construction of the satellite school. Hence, due to the construction of the satellite school, the children of the land reform beneficiaries have a school in close proximity to their homes. On average the children of land reform beneficiaries were now walking two kilometres to school.

In this paper, the researchers chose evidence from one case study. Creswell and Poth $(2018,96)$ explain that "case study research" involves "a qualitative approach that explores a real life, contemporary bounded system (a case) ... over time through detailed, in-depth data collection involving multiple sources of information." Furthermore, Thompson $(2010,40)$ states, "case studies are good for describing and expanding the understanding of a phenomenon and are often used to study people and programmes particularly in education. A case study can offer a refinement of understanding." We note that there are different case study typologies that can be used in research. Yin (2014) distinguishes between a single case design and a multiple case design. For this paper, we chose "a single instrumental case study," which "focuses on an issue or concern and then selects one bounded case to illustrate this issue" (Creswell and Poth 2018, 98). For this paper, evidence was extracted from one case study to provide a larger picture of the reasons why the land reform beneficiaries support the satellite school. In addition, "case studies provide an opportunity for the researcher to gain a deep holistic view of the research problem, and may facilitate describing, understanding and explaining a research problem or situation" (Baxter and Jack 2008, 545). In this paper, the case study approach aimed at obtaining a wealth of data on why the land reform beneficiaries were supporting the satellite school.

Our rationale for choosing the Tiro community was that it provides a case of steadfast commitment by land reform beneficiaries to harness their social capital in order to 
educate their children despite fluctuating income from their agricultural yields. It was evident that the land reform beneficiaries were capitalising on the benefits accruing from their social networks and nhimbe for their continued engagement in meeting the needs of the satellite school. Therefore, it can be argued that the Tiro community provides a unique case which needed to be interrogated.

Nine participants were purposively selected from the one case study community, given the pseudonym Tiro. Bryman (2010) explains purposive sampling as the selection of particular people as participants for a specific study. Fraenkel, Wallen and Hyun (2012, 100) discern "that qualitative researchers prefer purposive sampling since it allows them to use their personal judgments to select participants that they believe will provide the data they need." Furthermore, Silverman $(2013,148)$ explains that "purposive sampling demands that we think critically about the parameters of the population we are studying and choose our sample case carefully on this basis." What we wanted through purposive sampling was a case that was "information-rich ... which can be studied in-depth" (Patton 1990, 478). Thus, purposive sampling resonated with the aims of the present study.

In this article the unit of analysis is the land reform beneficiaries. The data was generated from one satellite school head and two village heads through semi-structured interviews and a focus group discussion with six land reform beneficiaries. We utilised the interview format because we wanted to understand the world from the subjects' point of view (Brinkmann and Kvale 2015,3). We chose the semi-structured type of interview because, as Gill and Johnson $(2002,291)$ explain, it "consists of several key questions that help to define the areas to be explored, but also allows the interviewer or interviewee to diverge in order to pursue an idea or response in more detail." Furthermore, it can be argued that there is flexibility in this method which allows for the expansion of data that is valuable to the participants, but which may not have been considered as relevant by the researcher beforehand (Gill and Johnson 2002). Therefore, three participants (one satellite school head and two village heads) were asked several key questions on what influences the land reform beneficiaries to play a central role in the development and support of the satellite school in their community. The focus group discussion was a follow-up from the interview and was used to probe and provide depth on certain themes which arose because we also believed that "interactions among the interviewees would likely yield the best information" (Creswell and Poth 2018, 164). The ethical clearance for this study was granted by the University of KwaZulu-Natal (Protocol reference number: HSS/1221/015D).

\section{The Research Findings}

The major themes that emerged from the data on the reasons for the land reform beneficiaries' development of and continued support for a satellite school stem from a marriage of interrelated reasons which feed off each other, comprising the following: the close proximity of the land reform beneficiaries' homesteads to each other and a 
feeling of indebtedness that they all had to the Mugabe government. Other reasons included the existence and growth of social networks amongst them, the traditional practice of nhimbe, the shared meaning and goals of the land reform beneficiaries, a sense of belonging amongst the land reform beneficiaries and their existing resource base. These themes are shown in Figure 1 below and discussed in depth below.

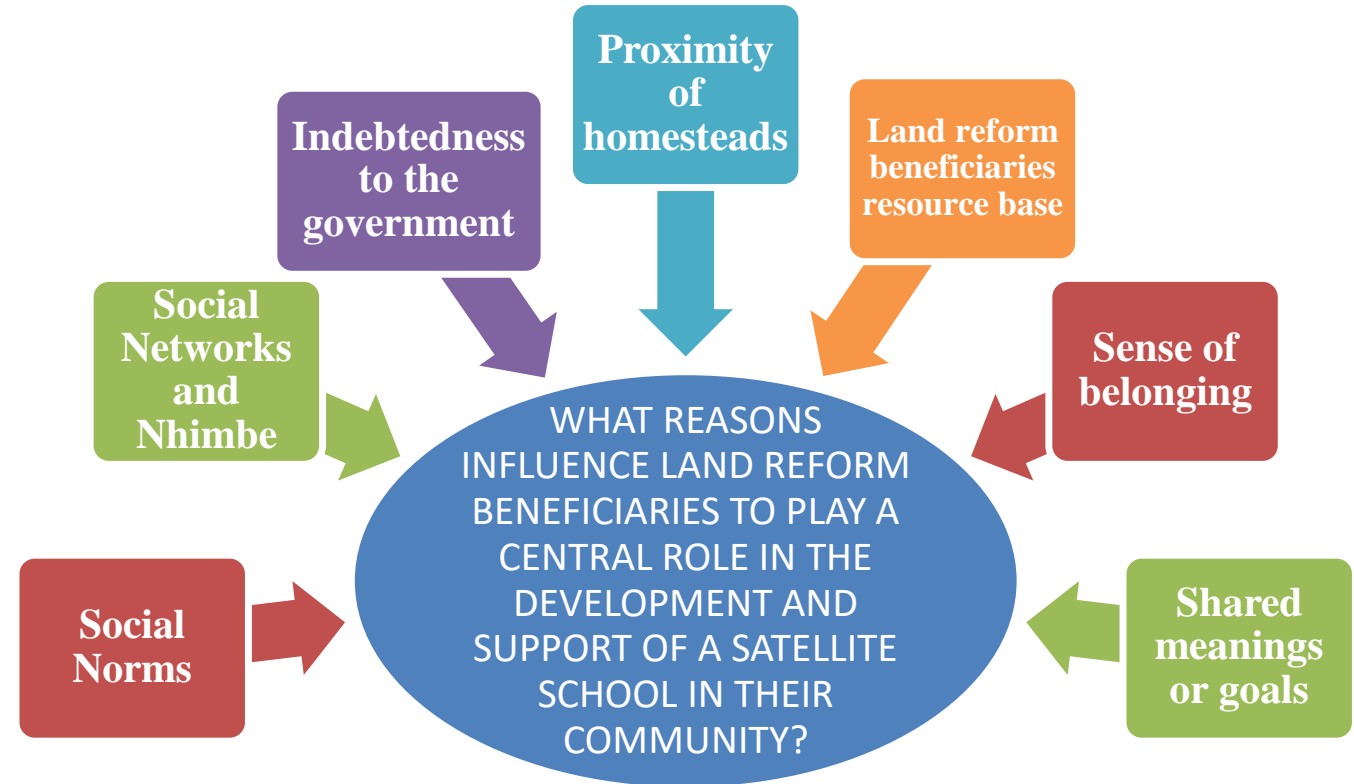

Figure 1: Reasons for the land reform beneficiaries developing and supporting the satellite school in Tiro (Field data: 2015)

\section{Social Networks and Nhimbe}

The study established that land reform beneficiaries played a central role in the development and support of the satellite school in their community due to the existing social networks amongst them; these grew with their continuous interactions because of households being located close to each other, which is a result of the land reform process as undertaken by the Zimbabwean government. A satellite school head who participated in this study revealed that,

For our school to be where it is today, we are grateful of the social networks of the farmers especially their nhimbe. ${ }^{2}$ The local farmers participated in nhimbe during

\footnotetext{
${ }^{2}$ Nhimbe-work party whereby farmers rotate working on each other's plots. At times as many as 10 households come together to work on each other's plots on a rotational basis.
} 
planting, weeding and harvesting. Nhimbe allows them to share ideas and encourages cooperation amongst the farmers' households.

More details on what the concept of nhimbe entails were elucidated in the focus group discussion. Another participant in the discussion explained,

Nhimbe is when neighbours take turns to provide labour on each other's plots. For example, Mr Shumba, Mr Hungwe and Mr Moyo bring their families to assist Mr Garwe and his family harvest his maize crop. Mr Garwe provides food and refreshments to his neighbours assisting him. The neighbours take turns and this cultivates good relations and neighbourliness.

During the nhimbe the host farmer provides food and refreshments as a token of appreciation. Among the Shona people of Zimbabwe there is a proverb, ukama igasva hunozadziswa nekudya ("a relationship is weak, it is only cemented by food"). Thus, the provision of food during the nhimbe strengthens the bond in the social networks. Furthermore, another participant in the focus group discussion elaborated "the nhimbe concept has been harnessed and extended to provide labour for the construction of our school. The farmers applied the nhimbe structures already in place to organise and mobilise labour for the construction of the school." A village head who participated in this study stated, "Nhimbe was used to clear the land, mould bricks, ferry river and pit sand, fetch water, fence and crush quarry stones at our school." The above verbatim narrations by the participants reveal that nhimbe influenced land reform beneficiaries to develop and support the satellite school in their community. The study revealed that the social networks amongst the land reform beneficiaries were strengthened during farming activities such as harvesting. Resultantly, this was then extended to undertaking building tasks for the construction of the satellite school. Hence, we argue that nhimbe was instrumental in the sharing of information pertaining to the development of the satellite school. These findings on the nhimbe concept are also supported by Manona $(2005,136)$ who posits that "nhimbe is an organised labour party which occurs through a relationship of reciprocity within a community." Therefore, it was explained that nhimbe played an important role in influencing land reform beneficiaries to play a central role in the development and support of the satellite school in the Tiro community.

\section{Social Norms and Practices}

The study further revealed that land reform beneficiaries played a central role in the development and support of the satellite school in their community due to their social norms. One village head revealed, "provision of labour at our school by every household is an expectation of our community. Who are you to go against what has been agreed by all other farmers?" It is important to note that there is no agreement in writing; the agreement is a verbal undertaking by the land reform beneficiaries in Tiro as a community. In addition, another participant remarked, "it doesn't matter whether you are new to the community. Even new farmers who recently joined the community are 
expected to conform and participate in community development." The role of social norms in the community was further revealed by a participant who stated, "as a new community created by the land reform, we have expectations from each household. Each household is obliged to contribute to the construction of our school."

Thus, the findings from this study indicated that there were social norms amongst the land reform beneficiaries who understood that they are a new community created by the process of land reform in Zimbabwe and that they needed to work as a collective. These social norms relate to households contributing to development in the community of Tiro in Masvingo district, in the same way as nhimbe contributes to working together during the harvesting season, and this facilitated the construction of the satellite school. Every land reform beneficiary's household was expected to adhere to these social norms and this proved to be beneficial to the satellite school, for example, in the provision of labour for the building of the school. The social norms of the land reform beneficiaries prioritised community development as explained above. It contributed to the education of their children through the construction of the school which was a key aspect of Tiro's community development. Consequently, the social norms and practices of the land reform beneficiaries of Tiro in Masvingo, Zimbabwe were a positive influence in terms of their central role in the development and support of the satellite school in their community. It should also be noted that nhimbe was a practice which was accepted in Tiro and this practice united the land reform beneficiaries in achieving their goals of agricultural harvesting of crops and building the school. These findings on the role of social norms and practices concur with the findings of Barnard's (2014) study. That study, undertaken among Brazilian farmers, demonstrated the importance of social norms in fostering community participation in development projects. Hence, it can be argued from the study's findings that social norms and practices influenced land reform beneficiaries to play a central role in the development and support of a satellite school in their community.

\section{Close Proximity of Homesteads to Each Other}

The participants in the study from Tiro community revealed that their central role in the development and support of the satellite school was largely born out of the close proximity of their homesteads to that of their neighbours, which was due to the Zimbabwean government's land reform allocation of plots. It emerged from the village head that the land reform beneficiaries' and village heads' homesteads were in close proximity to each other which enabled them to interact regularly with each other in discussions about the satellite school. One participant revealed,

Our homesteads are arranged very close together such that we see each other daily. Information is easily shared because we talk together daily. Our fields are delineated separately from our homesteads. Information on activities at our school was easily shared due to closeness of our homesteads. 
Additionally, another participant revealed, "our interaction with each other and our school was largely due to the proximity of our homesteads. Relations were easily established amongst us land reform beneficiaries due to the proximity of our homesteads which favoured daily interactions." The participants revealed that the short distance between the homesteads of the land reform beneficiaries (as allocated by the government) facilitated an easy sharing of information as there was more interaction amongst the land reform beneficiaries with regards to the satellite school and the tasks that needed to be completed for its development. Therefore, the proximity of the households of the land reform beneficiaries, a result of the government's land allocation to the farmers during land reform, increased their daily interactions which also had the positive impact of sharing of information about the needs of the satellite school. This finding revealed that there was easy information sharing among the land reform beneficiaries, such as information on stakeholder meetings known as pfinga mwedzi (monthly meetings convened by the traditional leadership to discuss developmental issues such as the construction of satellite schools) relating to the satellite school which was easily and quickly shared amongst the farmers. This close proximity of the homesteads, as allotted by the Zimbabwean government which was committed to the process of land reform, was thus essential in influencing the land reform beneficiaries' relationship to each other, allowing for the practice of nhimbe to become significant in achieving community goals such as the development of the satellite school. It took Tiro community two years to construct two classroom blocks although they had initially envisaged completion within a year.

The village heads and land reform beneficiaries were in agreement in respect of the impact of the proximity of their homesteads in determining the land reform beneficiaries' central role in the development and support of the satellite school in Tiro. Various studies (Fontein 2009; Marongwe 2009) acknowledge that the A1 model of land reform, which has been termed the villagised model, was composed of land reform beneficiaries' households which were in close proximity to one another. The households were located within a radius of 30 metres of each other. Thus, there are regular interactions amongst the community members on a daily basis. The land reform beneficiaries' regular interaction with each other was further enhanced by their shared water sources and their grazing lands. Land reform beneficiaries shared information on the construction of the satellite school at water sources. In addition, dates and times for important school meetings were also shared at the water sources. The households in the A1 model were clustered together while their fields and grazing lands were located away from the compounds which also influenced nhimbe. Hence, due to the proximity of the land reform homesteads to one another, there was the ripple effect of coordination of the satellite schools' activities: the decisions that were made in the fields translated to the work being undertaken at the satellite school. The local leadership utilised the proximity of the land reform beneficiaries' households to facilitate their continued support for the satellite school. Evidently, the closeness of homesteads can be argued to be an enhancer of bonding social capital. Putnam (1993) asserted that geographic 
proximity increases bonding social capital. Thus, this study exposed that due to the close proximity of the land reform beneficiaries' homesteads to one another, there was an increase in the beneficiaries' bonding social capital, which in turn improved their contribution to the development and support of the satellite school in Tiro. The land reform beneficiaries were able to attend important meetings which contributed to the construction of the satellite school. This is one example of what Putnam $(1995,67)$ terms "co-ordination and co-operation." The Tiro community took six months to complete the construction of a block of toilets. In addition, the geographic proximity facilitated the harnessing and coordination of regular labour towards the construction of the satellite school.

\section{Land Reform Beneficiaries' Indebtedness to the Mugabe Government}

The study further revealed that the land reform beneficiaries played a major role in the development and support of the satellite school in Tiro through mobilising their resources and sharing information because they felt indebted to the Mugabe government for giving them land as part of the land reform process which the government had promised its citizens. The land reform beneficiaries' indebtedness to the government in general and to the then President of Zimbabwe, Robert Mugabe, in particular was evident during both the semi-structured interviews and the focus group discussion with participants. One village head explained,

Cde Mugabe gave us land and we have to support him. One way of supporting him is through participating and contributing to the development of schools. Schools are close to our president's heart, so we are paying him back by building satellite schools in our area.

In addition, one land reform beneficiary elaborated on the building of the school, which is a contribution to public infrastructure: "We got land from the government without paying even a cent. Now it is our turn to help the government to develop our area." Therefore, the participants in this study demonstrated reciprocity again (which is the cornerstone of nhimbe) and they further suggested that the satellite school was a way of showing their gratitude for receiving the land during the government's land reform programme. Land reform beneficiaries thus contributed their labour towards the construction of the satellite school due to a feeling of indebtedness to the Mugabe government for fulfilling its promise of land reform.

\section{Land Reform Beneficiaries' Resource Base}

This study further highlighted that the role played by the land reform beneficiaries in the development and support of the satellite school in Tiro community was largely premised on their existing resource base. One land reform beneficiary revealed, "we are supporting our school because we are getting good yields. Our harvests allow us to sell our surplus, educate our children as well as support development. Schools are 
development." This view was supported by the Tiro satellite school head who observed that "land reform beneficiaries are doing well on their farms and they can afford to spare their yields, resources and labour towards the construction of schools in their communities." This finding on the yields of the land reform beneficiaries was consistent with the empirical findings of Scoones et al. (2010) in Masvingo province that the land reform beneficiaries were producing and accumulating assets. Therefore, the satellite school can be viewed as an asset within the community. Various studies (Cliffe et al. 2011; Moyo et al. 2009; Scoones 2016) also support this finding that the land reform beneficiaries are getting good yields, but this study revealed that the yields were not always consistent. Furthermore, these above-mentioned studies do not elaborate on the dimensions revealed in this study that the land reform beneficiaries utilised both their individual (labour and surplus maize) and collective resources (building materials such as river sand, water and quarry stones sourced from their environment) to support the satellite school. The land reform beneficiaries of Tiro community due to their own investment in infrastructure (such as building their own homesteads) provided accommodation to teachers who were later sent by the government to teach at the satellite school. Tarisayi and Manik (2017) established that land reform beneficiaries converted their surplus maize, when the yield was good, into cash which was donated to the satellite school for further development. Matondi $(2012,175)$ concurs that in Mazowe and Magwe districts "capital investment took place not only at farm level but also at the community level, as proceeds from farming were channelled to public infrastructure such as schools." Therefore, this paper argues that the central role played by the land reform beneficiaries in the development and support of satellite schools was largely dependent on the possession of adequate resources amongst members of the community of Tiro. Thus, the land reform beneficiaries, due to their land ownership and productive fields, were investing in education by converting their crops such as maize into capital to build the school. We further noted that there were indeed seasonal fluctuations in land reform beneficiaries supporting the satellite school. During the harvest season, the land reform beneficiaries have a strong resource base whilst in the planting season their resource base diminishes. Hence, the shifting resource base, depending on the season, contributed to the extent to which the land reform beneficiaries participated in the development and support of the satellite school.

\section{A Sense of Belonging and Ownership}

This study further showed that the land reform beneficiaries played a principal role in the development and support of the satellite school because they have a sense of belonging and ownership of the satellite school in their land reform community as they had met and maintained a relationship with the village head. They collectively lobbied the Zimbabwean government to provide a school which was needed as a result of the land reform process of allocating farms to its citizens. The government merely provided teachers to the satellite school and the land reform beneficiaries had to build their own school. A land reform beneficiary stated, "the local satellite school is our school and no one can build it for us. This school is like our own home so we have to develop it. We 
have asked the head to put signposts which identify our school." A Tiro village head added, "this school is part of our village. So we have to take it as our own homesteads. Do you expect outsiders to build your own home for you? No. That's why it is important for us farmers to participate in the construction of satellite schools." This notion of identifying the school as belonging to the community is illuminated in the land reform beneficiaries' support for the satellite school through their resource mobilisation and information sharing. In addition, it can be argued that the land reform beneficiaries mobilised their resources, disseminated information and volunteered their time and resources because they felt a sense of ownership of the satellite school. The land reform beneficiaries' articulations show a strong sense of belonging and ownership of the satellite school, which explains their essential role in the development and support of the satellite school, for example through the provision of labour and building materials, among others. It can be maintained that the land reform beneficiaries in Tiro community demonstrated cohesiveness by supporting the satellite school through mobilising their resources and sharing information with each other because of their sense of belonging to that community and a belief in Tiro's ownership of the school.

\section{Shared Meanings and Goals}

The study further revealed that the land reform beneficiaries played a fundamental role in the development and support of the satellite school because there were shared meanings and goals amongst them given that they were all beneficiaries of the same process of land reform occupying a common area. "Shared meanings" in this study refers to a community viewing its problems in the same way and mutually arriving at a solution. One Tiro village head revealed how all land reform beneficiaries shared the same idea and were working towards the same goal: "We want our satellite school to grow and be popular. This school has to be a shining beacon and right now we feel we are heading in that direction. We were happy this year when the whole district came here for a sports tournament. That is how big names are made." Another participant in this study explained,

The community takes pride in the school. There is always tremendous support from the community when we host sports tournaments or any other function. This was witnessed when we hosted a district sports tournament earlier this year [2015]. The farmers' [land reform beneficiaries] support was overwhelming to say the least.

In addition, the Tiro community had a shared goal of completing the construction of two classroom blocks within a year, although it eventually took two years due to fluctuating yields. The other shared goal among the land reform beneficiaries in Tiro was constructing a block of toilets within six months. These findings concur with McMillan and Chavis $(1986,9)$ who explain the dynamics in a group which are shared, "a feeling that members have of belonging, a feeling that members matter to one another and to the group, and a shared faith that members' needs will be met through their commitment to be together." Therefore, it follows that the land reform beneficiaries as 
a group of farmers united by the land reform process collaborate as they do in the practice of nhimbe, mobilise their resources, and share information with each other about the satellite school due to a sense of their shared meanings and goals which they need to achieve. Nhimbe thus increases the capacity for development in the community. The communitarian approach of social capital benefits accruing to the entire community (Coleman 1988) is evident in Tiro. This in turn fosters community pride in the school and Tiro.

\section{Conclusions}

From the foregoing presentation of the findings, a number of conclusions can be reached related to the land reform beneficiaries and the satellite school in Tiro. The central role played by land reform beneficiaries and their reasons for developing and supporting the satellite school of Tiro in Masvingo district, Zimbabwe largely hinged on the social networks they had nurtured and developed due to the land reform process which allocated them plots close to each other. The land reform beneficiaries managed to capitalise on their social networks in the form of nhimbe to support the satellite school through mobilising their resources and sharing important information. Nhimbe was a product of reciprocal relations in Tiro. In addition, the social norms of the land reform beneficiaries were also instrumental in determining their central role and their reasons for developing and supporting the satellite school in their community. The land reform beneficiaries of Tiro community had certain expectations in terms of what they wanted to achieve for the school and these expectations formed the foundation for their plans and their initiatives to reach that goal as a community resulting from the land reform process. The land reform beneficiaries had lobbied the government for a school and they therefore had a sense of ownership of the satellite school in their community. It is also significant to note that the commitment of the land reform beneficiaries to the satellite school was greatly influenced by the close proximity of their homesteads to that of their neighbours as decided upon by government allocation of the land during the reform process. The close proximity of the land reform beneficiaries' homesteads to each other was instrumental in building their social networks, facilitating nhimbe and strengthening their daily interactions with each other. The homes were all within a three-kilometre radius of the satellite school. This expedited the development of the satellite school.

The land reform beneficiaries' role and reasons for developing and supporting the satellite school were also due to their existing resource base at a particular time of the year (seasonal variations resulted in fluctuations in progress). The study established that the land reform beneficiaries were investing in the education of their children because of their existing resource base (from harvesting maize) which permitted them to contribute various forms of capital leading to the continued development of the satellite school which has become an asset to their community of Tiro. Thus, the land allocated as per the land reform process has increased Tiro's community resource base by facilitating the attainment of a community asset, the satellite school. 
The land reform beneficiaries were also indebted to the Mugabe government for receiving the land without having to pay for it. Among the land reform beneficiaries were formerly landless peasants who felt greatly indebted to the government and they were keen to use their participation in community development initiatives like the construction of the satellite school as a way of showing their indebtedness. Therefore, we conclude that a gap in the provision of educational services for land reform communities has been addressed by the land reform beneficiaries of Tiro community themselves. Therefore, this satellite school can be viewed as a beacon of educational hope for other land reform communities which have a relatively strong resource base, where the government has not as yet constructed schools. The educational needs of the children from Form One to Form Four in the land reform community of Tiro are being met through the key role of the land reform beneficiaries in developing and supporting the satellite school in their community.

\section{References}

Barnard, D. G. N. 2014. "The Role of Social Capital in Household Economy and Land Use/Land-Cover Change in Areas of Land Reform in Santarém, Brazilian Amazon." PhD diss., Indiana University.

Baxter, P., and S. Jack. 2008. "Qualitative Case Study Methodology: Study Design and Implementation for Novice Researchers.” The Qualitative Report 13 (4): 544-59.

Brinkmann, S., and S. Kvale.2015. Interviews: Learning the Craft of Qualitative Research Interviewing. 3rd ed. Thousand Oaks, CA: Sage.

Bryman, A. 2010. Social Research Methods. Oxford: Oxford University Press.

Cliffe, L., J. Alexander, B. Cousins, and R. Gaidzanwa. 2011. "An Overview of Fast Track Land Reform in Zimbabwe: Editorial Introduction.” In "The Outcomes of Post-2000 Fast Track Land Reform in Zimbabwe,” edited by Cliffe, L., J. Alexander, B. Cousins, and R. Gaidzanwa, special issue, The Journal of Peasant Studies 38 (5): 90-38. https://doi.org/10.1080/03066150.2011.643387.

Coleman, J. S. 1988. "Social Capital in the Creation of Human Capital." The American Journal of Sociology 94: 95-120. https://doi.org/10.1086/228943.

Creswell, J. W., and C. N. Poth. 2018. Qualitative Inquiry and Research Design: Choosing Among Five Approaches. 4th ed. Thousand Oaks, CA: Sage

Fontein, J. 2009. "We Want to Belong to Our Roots and We Want to be Modern People: New Farmers, Old Claims around Lake Mutirikwi, Southern Zimbabwe." African Studies Quarterly 10 (4): 1-35.

Fraenkel, J. R., N. E. Wallen, and H. H. Hyun 2012. How to Design and Evaluate Research in Education. New York, NY: McGraw-Hill. 
Gill, J., and P. Johnson. 2002. Research Methods for Managers. 3rd ed. London: Sage.

Hlupo, T., and J. Tsikira. 2012. "A Comparative Analysis of Performance of Satellite Primary Schools and Their Mother Schools in Masvingo Province, Zimbabwe." Journal of Emerging Trends in Educational Research and Policy Studies 3 (5): 604-10.

Kabayanjiri, K. 2012. "Overview of Satellite Schools in Resettled Areas.” Accessed May 21, 2015. http://www.parlzim.gov.zw/attachments/article/35/20/.

Manona, S. S. 2005. “Small Holder Agriculture as Local Economic Development (LED) Strategy in Rural South Africa. Exploring Prospects in Pondoland, Eastern Cape.” PhD diss., University of Western Cape.

Marongwe, N. 2009. "Redistributive Land Reform and Poverty Reduction in Zimbabwe." Livelihoods after Land Reform Working Paper, 1-41. Accessed October 28, 2019. https://assets.publishing.service.gov.uk/media/57a08ae4ed915d622c000985/60332_Zimba bwe_Land_Reform.pdf.

Matondi, P. B. 2012. Zimbabwe's Fast Track Land Reform. London: Zed Press.

McMillan, D. W., and D. M. Chavis. 1986. "Sense of Community: A Definition and Theory." In "Psychological Sense of Community, I: Theory and Concepts," edited by J. R. Newbrough and D. M. Chavis, special issue, Journal of Community Psychology 14 (1): 623. https://doi.org/10.1002/1520-6629(198601)14:1<6::AID-JCOP2290140103>3.0.CO;2I.

Moyo, S., W. Chambati, T. Murisa, D. Siziba, C. Dangwa, K. Mujeyi, and N. Nyoni 2009. Fast Track Land Reform Baseline Survey in Zimbabwe: Trends and Tendencies, 2005/06. Harare: African Institute for Agrarian Studies. Accessed October 28, 2019. http://aiastrust.org/wp-content/uploads/2015/10/Interdistrct-Survey-Report19July2010.pdf.

Murisa, T. 2010. "Social Development in Zimbabwe.” Discussion Paper prepared for Development Foundation Zimbabwe. Accessed October 28, 2019. https://www.dfzim.com/wpcontent/downloads/Social_Development_in_Zimbabwe_by_Dr_T_Murisa.pdf.

Mutema, E. P. 2012. "The Fast Track Land Reform Programme: Reflecting on the Challenges and Opportunities for Resettled Former Farm Workers at Fairfield Farm in Gweru District, Zimbabwe." Journal of Sustainable Development in Africa 14 (5): 96-106.

Mutema, F. 2014. "An Examination of the Learning Conditions in Zimbabwe's Satellite Schools: A Case of Somabhula Resettlement Area-Midlands Province.” International Journal of Humanities and Social Science 4 (8): 284-90. Accessed October 29, 2019. http://www.ijhssnet.com/journals/Vol_4_No_8_1_June_2014/32.pdf. 
Parliament of Zimbabwe. 2012. First Report on the Thematic Committee on the Millennium Development Goals on the Provision of Education in Resettled Areas. Harare: Zimbabwe.

Patton, M. Q. 1990. Qualitative Evaluation and Research Methods. Newbury, CA: Sage.

Putnam, R. D. 1993. Making Democracy Work: Civic Traditions in Modern Italy. Princeton, NJ: Princeton University Press. https://doi.org/10.2307/j.ctt7s8r7.

Putnam, R. D. 1995. “Bowling Alone: America's Declining Social Capital.” Journal of Democracy 6 (1): 65-78. https://doi.org/10.1353/jod.1995.0002.

Putnam, R. D. 2000. Bowling Alone: The Collapse and Revival of American Community. New York, NY: Simon and Schuster. https://doi.org/10.1145/358916.361990.

Scoones, I. 2016. "Mvurwi: From Farm Worker Settlement to Booming Business Centre.” New Zimbabwe, May 26. Accessed October 28, 2019.

https://www.newzimbabwe.com/mvurwi-from-farm-worker-settlement-to-boomingbusiness-centre/.

Scoones, I., N. Marongwe, B. Mavedzenge, F. Murimbarimba, J. Mahenehene, and C. Sukume. 2010. Zimbabwe's Land Reform: Myths and Realities. Harare: Weaver Press.

Shizha, E., and M. T. Kariwo. 2011. Education and Development in Zimbabwe: A Social, Political and Economic Analysis. Rotterdam: Sense Publishers. https://doi.org/10.1007/978-94-6091-606-9.

Silverman, D. 2013. Doing Qualitative Research: A Practical Handbook. Thousand Oaks, CA: Sage.

Tarisayi, K. S. 2015. "An Exploration of the Challenges Encountered by Satellite Schools in Masvingo District, Zimbabwe.” Journal for Studies in Management and Planning 1 (9): 304-8. Accessed October 28, 2019.

https://internationaljournalofresearch.com/2016/11/28/an-exploration-of-the-challengesencountered-by-satellite-schools-in-masvingo-district-zimbabwe/.

Tarisayi, K. S. 2017. "The Social Capital Influences of Land Reform Beneficiaries and Communal Farmers on Satellite Schools in Zimbabwe." PhD diss., University of KwazuluNatal. Accessed October 28, 2019. https://researchspace.ukzn.ac.za/bitstream/handle/10413/15337/Tarisayi_Kudzayi_savious _2016.pdf?sequence=1\&isAllowed=y.

Tarisayi, K. S., and R. Manhibi. 2017. “Acrimony or Harmony? The Case of Relations between Mother Schools and Their Satellite Schools in a Selected District in Masvingo Province." International Journal of Academic Research in Business and Social Sciences 7 (11): 441-47. https://doi.org/10.6007/IJARBSS/v7-i11/3480. 
Tarisayi, K. S., and S. Manik. 2017. "Social Networks among Land Reform Beneficiaries and Their Use in Supporting Satellite Schools in Zimbabwe: A Case Study of a Satellite School." Education as Change 21 (3): 1-17. https://doi.org/10.17159/19479417/2017/2091.

Thompson, S. W. 2010. "The Caring Teacher: A Multiple Case Study that Looks at What Teachers Do and Believe about Their Work with At-Risk Students.” PhD diss., University of Nebraska. Accessed October 28, 2019. https://digitalcommons.unl.edu/cgi/viewcontent.cgi?article=1074\&context=cehsdiss.

Yin, R. K. 2014. Case Study Research Design and Methods. 5th ed. Thousand Oaks, CA: Sage.

Zvavahera, P. 2015. "Human Capital Management in Zimbabwean Rural Schools: A SocioEconomic Analysis.” Journal of Management and Marketing Research 18: 1-10. Accessed October 28, 2019. https://www.aabri.com/manuscripts/142060.pdf. 